\title{
FABRICATION OF Mg-Zn-Al HYDROTALCITE AND ITS APPLICATION FOR $\mathrm{Pb}^{2+}$ REMOVAL
}

\author{
Eddy Heraldy ${ }^{a, b, *}$, Fitria Rahmawati ${ }^{a, b}$, Dwi ARdiyanti ${ }^{a}$, \\ IKA NURMAWANTI ${ }^{a}$ \\ a Sebelas Maret University, Faculty of Mathematics and Natural Sciences, Department of Chemistry, Jl. Ir. A. \\ Sutami 36A, Kentingan, Surakarta 57126, Indonesia \\ ${ }^{b}$ Sebelas Maret University, Chemistry Department, Solid State Chemistry and Catalyst Reseach Group, Jl. Ir. A. \\ Sutami 36A, Kentingan, Surakarta 57126, Indonesia \\ * corresponding author: eheraldy@mipa.uns.ac.id
}

\begin{abstract}
The fabrication of Mg-Zn-Al Hydrotalcite (HT) was carried out by the co-precipitation method at various molar ratios. The Mg-Zn-Al HT compound at the optimum molar ratio was then calcined to determine the effect of calcination on the $\mathrm{Pb}^{2+}$ adsorption. The kinetics of the adsorption type was determined by applying pseudo first order and pseudo second order kinetics models. Meanwhile, to investigate the adsorption process, the Freundlich and Langmuir equations were applied to determine the adsorption isotherm. The results showed that the optimum Mg-Zn-Al HT was at a molar ratio of $3: 1: 1$ with an adsorption efficiency of $73.16 \%$, while $\mathrm{Mg}$-Zn-Al HT oxide increased the adsorption efficiency to $98.12 \%$. The optimum condition of $\mathrm{Pb}^{2+}$ removal using $\mathrm{Mg}-\mathrm{Zn}-\mathrm{Al}$ HT oxide was reached at $\mathrm{pH} 5$ and a contact time of 30 minutes. The adsorption kinetics follows the pseudo second order kinetics model with a rate constant of $0.544 \mathrm{~g} / \mathrm{mg} \cdot \mathrm{min}$. The isotherm adsorption follows the Langmuir isotherm model with a maximum capacity of $3.916 \mathrm{mg} / \mathrm{g}$ and adsorption energy of $28.756 \mathrm{~kJ} / \mathrm{mol}$.
\end{abstract}

KEYwords: Adsorption, isotherm, kinetics, $\mathrm{Mg}-\mathrm{Zn}-\mathrm{Al}$ hydrotalcite, $\mathrm{Pb}^{2+}$ removal.

\section{INTRODUCTION}

Hydrotalcite compounds (HT), which are also known as Layered Double Hydroxides (LDH) or anionic clays, is are layered materials that have an anion exchange capacity and a large surface area [1]. The HT compounds have a general formula: [M(II)1$\left.\mathrm{xM}(\mathrm{III}) \mathrm{x}(\mathrm{OH})^{2}\right] \mathrm{x}+(\mathrm{An}-) \mathrm{x} / \mathrm{n} . \mathrm{mH}^{2} \mathrm{O}$; in which, $\mathrm{M}(\mathrm{II})$ is a divalent metal cation, and $\mathrm{M}(\mathrm{III})$ is a trivalent metal cation. The An- is a balancing anion with $\mathrm{x}$ as the molar ratio fraction and $m$ as the number of water molecules in the interlayer [1, 5]. The replacement of several M(II) by M(III) cations in the HT structure causes the hydroxide layer to be of an excess positive charge. The excess positive charge is balanced by an interlayer consisting of anions and water molecules 6] 8 .

Some researchers applied the HT for a metal cation adsorption including an adsorption of $\mathrm{In}^{3+}$ by $\mathrm{Zn}-\mathrm{Al}$ $\mathrm{LDH}$ [9, adsorption of $\mathrm{Cr}^{6+}$ using $\mathrm{Mg}-\mathrm{Al} \mathrm{LDH}, \mathrm{Ni}-\mathrm{Al}$ $\mathrm{LDH}$ and $\mathrm{Zn}-\mathrm{Al} \mathrm{LDH}$ [10]. Adsorption of $\mathrm{Cu}^{2+}$ by Ca-Al-Zn LDH oxide [11, and $\mathrm{Pb}^{2+}$ adsorption using LDH Co-Mo [12]. The previous study shows that the $\mathrm{HT}$ is a potential adsorbent for $\mathrm{Pb}^{2+}$, even though the HTs also bear a positive charge on the hydroxide layer. The positive charge on the surface of the HT will interact with hydroxide ions in the solution that forms metal hydroxide on the HT surface [9. In addition, a calcination treatment at $400-500^{\circ} \mathrm{C}$ can convert the HT to a metal oxide [13. If the metal oxide is dispersed into water, it will re-construct the
HT layered structure. This is named as the memory effects. This unique character causes the HT to be widely used as adsorbent, such as namely for heavy metal pollutants [3, 5].

The heavy metal pollution is dangerous for the human health [14-16]. The $\mathrm{Pb}^{2+}$ ion is a kind of heavy metals frequently found in liquid waste 3 . Due to the negative impacts of lead, therefore, the presence of lead in the environment must comply with regulations. Several methods have been applied to reduce the lead metal content from in a liquid waste, such as precipitation method, ion exchange, electrolysis, membrane filtration, and adsorption [17, 18. The adsorption method is considered, as the most effective method due to lesser cost required. In addition, the absorption capacity is higher, the process is simple, and the efficiency is relatively high and does not provide have side effects in the form of toxic substances [19. Numerous adsorbents, for example, tourmaline, biosorbent, montmorillonite, activated carbon, zeolite, waste biomass, wheat straw, black phosphorous nanosheet, and Sulfur-doped Graphitic Carbon Nitride had been reported [20 28$]$.

Therefore, the current study focused on a synthesis of $\mathrm{Mg}-\mathrm{Zn}-\mathrm{Al} \mathrm{HT}$ by a co-precipitation method and their its possibility as an effective and economical adsorbent for the $\mathrm{Pb}^{2+}$ ion removal. The variable operating parameters such as the $\mathrm{pH}$ of a solution, initial concentration of lead ions, and contact time were examined. As the profile of adsorption equilibrium, was used the Langmuir and Freundlich isotherm 
was used. The adsorption behaviour occasionally was occasionally studied by kinetics studies.

\section{MATERIAL AND METHODS}

\subsection{MATERIALS}

Some materials for the Mg-Zn-Al HT synthesis were $\mathrm{Mg}\left(\mathrm{NO}_{3}\right)_{2} \cdot 6 \mathrm{H}_{2} \mathrm{O}, \mathrm{Al}\left(\mathrm{NO}_{3}\right)_{3} .9 \mathrm{H}_{2} \mathrm{O}, \mathrm{Zn}\left(\mathrm{NO}_{3}\right)_{2} \cdot 4 \mathrm{H}_{2} \mathrm{O}$, $\mathrm{K}_{2} \mathrm{CO}_{3}, \mathrm{KOH}, \mathrm{HNO}_{3}$ and $\mathrm{Pb}\left(\mathrm{NO}_{3}\right)_{2}$ standard solution. All chemical reagents are analytical grade and were procured from Merck, Indonesia. All were used without any further purification.

\subsection{Procedure}

\subsubsection{FABRICATION OF Mg-Zn-Al HT ADSORBENTS}

The Mg-Zn-Al HT was fabricated from $\mathrm{Mg}\left(\mathrm{NO}_{3}\right)_{2} \cdot 6 \mathrm{H}_{2} \mathrm{O}, \quad \mathrm{Al}\left(\mathrm{NO}_{3}\right)_{3} .9 \mathrm{H}_{2} \mathrm{O} \quad$ and $\mathrm{Zn}\left(\mathrm{NO}_{3}\right)_{2} \cdot 4 \mathrm{H}_{2} \mathrm{O}$ by the co-precipitation method in an alkaline media at a constant $\mathrm{pH}$ [29]. The molar ratios of $\mathrm{Mg}: \mathrm{Zn}: \mathrm{Al}$ were $4: 0: 1,3: 1: 1,2: 2: 1$ and $1: 3: 1$. Based on the molar ratio, all chemicals were dissolved in $200 \mathrm{~mL}$ of distilled water. The $\mathrm{K}_{2} \mathrm{CO}_{3}$ and $\mathrm{KOH}$ were then added until the $\mathrm{pH}$ reached 10 . The mixture was then distilled at $80^{\circ} \mathrm{C}$ for $4 \mathrm{~h}$. The precipitate formed was washed with water until the $\mathrm{pH}$ reached 7 , and then it was dried at $100{ }^{\circ} \mathrm{C}$ for $24 \mathrm{~h}$. The prepared powder was then heated at $450^{\circ} \mathrm{C}$ for $5 \mathrm{~h}$ to produce the oxide of $\mathrm{Mg}-\mathrm{Zn}-\mathrm{Al}-\mathrm{HT}$.

\subsubsection{BATCH ADSORPTION EXPERIMENTS DESIGN}

Batch adsorption experiments were performed in a series of $250 \mathrm{~mL}$ conical flask containing $25 \mathrm{~mL}$ of $\mathrm{Pb}\left(\mathrm{NO}_{3}\right)_{2}$ solution. This solution was prepared to study the effect of the contact time $(15,30,60,90$ and $120 \mathrm{~min}) ; \mathrm{pH}(3,4,5$, and 6$)$; and the initial $\mathrm{Pb}^{2+}$ concentration $(10,20,30,40$ and $50 \mathrm{ppm})$ at $120 \mathrm{rpm}$. After the adsorption had finished, the solution was filtered and the filtrate was analysed by an atomic absorption spectrophotometer (AAS). The $\mathrm{Pb}^{2+}$ adsorption efficiency was calculated by the equation (1) 20, 30, 31]:

$$
\text { Adsorption efficiency }(\%)=\left\{\frac{C_{0}-C_{e}}{C_{0}}\right\} \times 100 \%
$$

The $C_{0}$ and $C_{e}$ are the initial concentrations of $\mathrm{Pb}^{2+}(\mathrm{mg} / \mathrm{L})$ at $t=0$ and the equilibrium concentration, respectively. The adsorption capacity $(q)$ was calculated by a mass balance equation of adsorbent as depicted in equation:

$$
q=\frac{\left(C_{0}-C_{e}\right) V}{W}
$$

In which, $V$ is the volume of the $\mathrm{Pb}^{2+}$ solution (L), and $W$ is the mass of the adsorbent $(\mathrm{g})$.

\section{ADSORBENTS OPTIMIZATION}

The adsorbents optimization was carried out by $0.05 \mathrm{~g}$ adsorbent with a various $\mathrm{Mg}: \mathrm{Zn}: \mathrm{Al}$ molar ratio of $4: 0: 1,3: 1: 1,2: 2: 1$, and $1: 3: 1$ with $10 \mathrm{~mL}$ of $\mathrm{Pb}^{2+} 5 \mathrm{ppm}$ solution. The adsorption was performed for $2 \mathrm{~h}$ at $120 \mathrm{rpm}$ speed. The remaining $\mathrm{Pb}^{2+}$ was analysed by AAS.

\section{Adsorbents EFFECTIVENESS TEST}

$0.05 \mathrm{~g}$ of the prepared $\mathrm{Mg}-\mathrm{Zn}-\mathrm{Al}-\mathrm{HT}$ adsorbent was added to $10 \mathrm{~mL}$ of the $\mathrm{Pb}^{2+} 5 \mathrm{ppm}$ solution. The mixture was stirred with a rotary shaker for $2 \mathrm{~h}$ at $120 \mathrm{rpm}$. The remaining $\mathrm{Pb}^{2+}$ in the solution was analysed by the AAS.

\section{The EFFECT OF PH SOLUTION}

The effect of the $\mathrm{pH}$ solution to the $\mathrm{Pb}^{2+}$ removal was investigated by conducting an adsorption experiment under various $\mathrm{pH}$ values of $3,4,5$ and 6 . A define

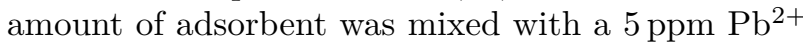
solution and then, it was agitated for $2 \mathrm{~h}$ at a room temperature. The remaining $\mathrm{Pb}^{2+}$ in solution was analysed by the AAS.

\section{THE EFFECT OF CONTACT TIME}

The adsorption process was conducted under various contact times 15, 30, 60, 90, and $120 \mathrm{~min}$ at the optimum $\mathrm{pH}$. The $\mathrm{Pb}^{2+}$ concentration was $5 \mathrm{ppm}$. Thereafter, samples were filtered and the $\mathrm{Pb}^{2+}$ content in the filtrate was determined using the AAS.

\section{The EFFECT OF $\mathrm{Pb}^{2+}$ ION CONCENTRATION}

In order to investigate the effect of the $\mathrm{Pb}^{2+}$ concentration, an adsorption experiment was conducted under the optimum $\mathrm{pH}$ for $120 \mathrm{~min}$. The experiment used various $\mathrm{Pb}^{2+}$ initial concentrations, i.e., 5, 10, $20,30,40$ and $50 \mathrm{ppm}$. The adsorption result was then filtered and the $\mathrm{Pb}^{2+}$ content in the filtrate was analysed by the AAS.

\section{Results AND Discussion}

\subsection{Characterization of Mg-Zn-Al HT}

\subsubsection{XRD ANALYSIS}

The identification of $\mathrm{Mg}-\mathrm{Zn}-\mathrm{Al}-\mathrm{HT}$ product samples was conducted by comparing 2 theta values from the peaks of the synthesized compounds with a standards of the Joint Committee on Powder Diffraction Standard (JCPDS). The JCPDS standards used are $\mathrm{Mg}-\mathrm{Al}$ hydrotalcite (JCPDS Number 89-0460) and Zn-Al hydrotalcite (JCPDS Number 38-0486). The diffraction patterns are presented in Fig. 1

According to Rodriguez-Chiang et al., 2016 [32]; Ghashghaee and Farzaneh (2018) 33, the main features of the HT were 2 theta at 11, 23, 35, 39, 46, 61, and $62^{\circ}$. Based on the 2 theta value, the fabricated $\mathrm{Mg}-\mathrm{Zn}-\mathrm{Al}-\mathrm{HT}$ is in an agreement with $\mathrm{Mg}-\mathrm{Al}-\mathrm{HT}$ and Zn-Al-HT as reported by Valente et al., 2010 [34, and Elsayed et al., 2016 2. This proves that divalent ions $\left(\mathrm{Mg}^{2+}\right.$ and $\left.\mathrm{Zn}^{2+}\right)$ and trivalent $\left(\mathrm{Al}^{3+}\right)$ are the 


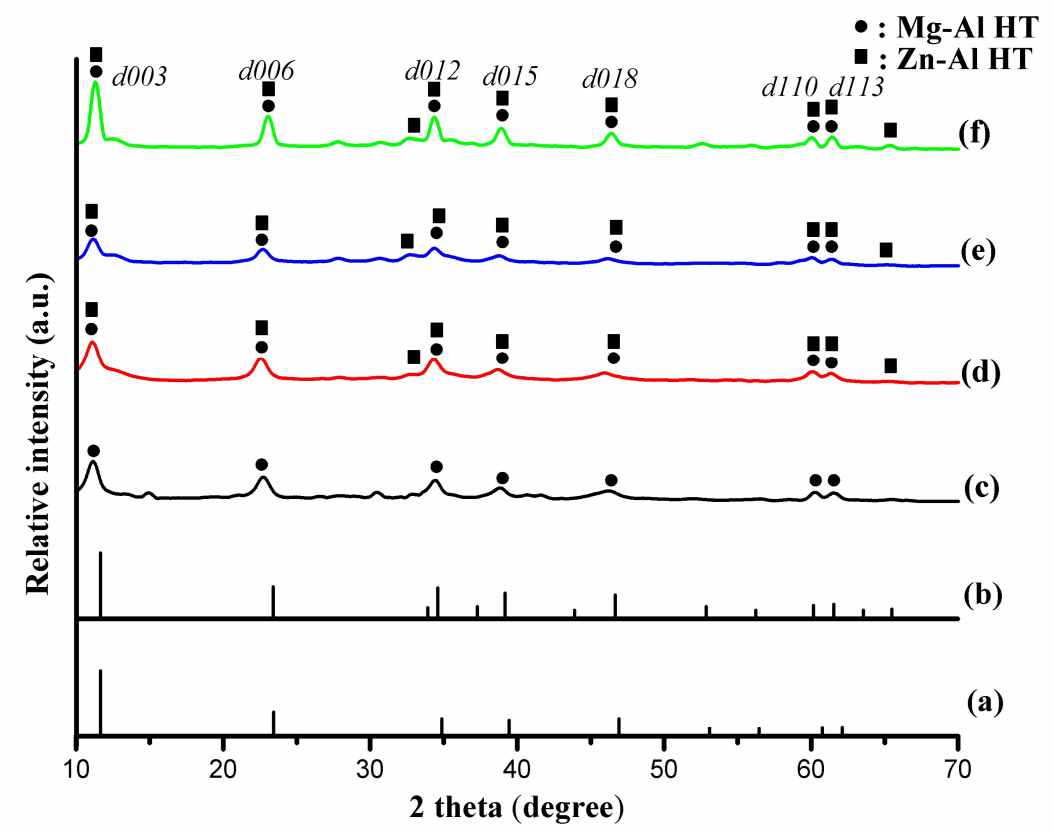

Figure 1. Diffractogram of (a) JCPDS Mg-Al-HT(b) JCPDS Zn-Al-HT (c) Mg-Al-HT (d) Mg-Zn1-Al HT (e) Mg-Zn2-Al HT (f) Mg-Zn3-Al HT.

constituent ions of Mg-Zn-Al-HT, which are bound in the HT layer together with the hydroxyl groups. In general, Mg-Zn-Al-HT is more likely to form a hydrotalcite compound in which the divalent ions that play a role are $\mathrm{Mg}^{2+}$ ions. However, $\mathrm{Zn}^{2+}$ ions are also bound in the HT layer with the hydroxyl groups and trivalent ions. This was proven by the appearance of a peak that is similar to the peak of Zn-Al-HT. The $\mathrm{Mg}^{2+}$ and $\mathrm{Zn}^{2+}$ ions, which are bound to the HT layer, can undergo exchanges due to the similar atomic radius difference. The dimensions of the $\mathrm{Mg}^{2+}$, $\mathrm{Zn}^{2+}$, and $\mathrm{Al}^{3+}$ radii are $0.72 \AA, 0.74 \AA$ and $0.54 \AA$, respectively [5, 35. According to Cavani et al., 1991 1, divalent metal cations with radii between $0.3-0.9 \AA$ and trivalent metal cations with radii of $0.5-0.8 \AA$ will form a more regular octahedral coordination with the hydroxyl groups.

\subsubsection{FTIR ANALYSIS}

Figure 2 shows four FTIR Mg-Zn-Al-HT spectrums at various molar ratios.

Fig. 2 shows the absorption at wavenumbers between $3490-3457 \mathrm{~cm}^{-1}$. That was identified as the absorption of $\mathrm{O}-\mathrm{H}$ group (hydroxyl) stretching. The $\mathrm{O}-\mathrm{H}$ group in the absorption is possible to come from a hydroxyl group that binds to $\mathrm{M}-\mathrm{OH}$ or it comes from $\mathrm{H}_{2} \mathrm{O}$, which is bound to the interlayer anion. The absorption in wavenumbers between 1642$1506 \mathrm{~cm}^{-1}$ is the absorption of $\mathrm{O}-\mathrm{H}$ groups bending that are possibly water molecules in the interlayer [25, 35, 36. The FTIR spectra of Mg-Al-Zn-HT also shows the absorption of wavenumbers in the area of $1384-1381 \mathrm{~cm}^{-1}$, which is a typical absorption of the $\mathrm{C}$ $\mathrm{O}$ group (carbonyl) of $\mathrm{CO}_{3}{ }^{2-}$ acting as an interlayer balancing anion [2, 5, 36]. The existence of divalent and trivalent metals in the structure of $\mathrm{Mg}-\mathrm{Zn}-\mathrm{Al}-$ HT can be seen with the appearance of the metal absorption bound to oxygen $(\mathrm{M}-\mathrm{O})$ at wavenumbers $414-835 \mathrm{~cm}^{-1}$. Wavenumbers in the $783 \mathrm{~cm}^{-1}$ regions are the absorption of $\mathrm{Al}-\mathrm{O}$ and $\mathrm{Zn}-\mathrm{Al}-\mathrm{O}$ at the hydrotalcite layer. In addition, the absorption at wavenumbers $670-620 \mathrm{~cm}^{-1}$ is the absorption of $\mathrm{C}=\mathrm{O}$ from carbonate vibrations, $590-560 \mathrm{~cm}^{-1}$ is the absorption of $\mathrm{M}-\mathrm{O}, \mathrm{M}-\mathrm{O}-\mathrm{M}$, and $\mathrm{O}-\mathrm{M}-\mathrm{O}$. While the absorption in wavenumbers $460-420 \mathrm{~cm}^{-1}$ is the absorption of $\mathrm{Mg}-\mathrm{OH}, \mathrm{Al}-\mathrm{OH}, \mathrm{Zn}-\mathrm{OH}$ at the hydrotalcite layer in the octahedral coordination [5].

\subsection{3. $\mathrm{Mg}-\mathrm{Zn}-\mathrm{Al}$ HT OptimizATION}

The effect of $\mathrm{Zn}^{2+}$ addition to the $\mathrm{Pb}^{2+}$ adsorption is shown in Fig. 3

In accordance with Fig. 3, it is known that the addition of $\mathrm{Zn}^{2+}$ is directly proportional to the $\mathrm{Pb}^{2+}$ ions adsorption efficiency. The efficiency of the $\mathrm{Pb}^{2+}$ adsorption on $\mathrm{Mg}-\mathrm{Zn} 1-\mathrm{Al} \mathrm{HT}$ with a molar ratio of $3: 1: 1$ is only $73.16 \%$. However, the efficiency of the $\mathrm{Pb}^{2+}$ adsorption to $\mathrm{Mg}-\mathrm{Zn}-\mathrm{Al} \mathrm{HT}$ with a molar ratio of $2: 2: 1$ and $1: 3: 1$ does not increase significantly. The Mg-Zn2-Al HT adsorbent has an adsorption efficiency of $75.48 \%$, while the Mg-Zn3-Al HT has an adsorption efficiency of $77.41 \%$. Therefore, for the optimization of the effect of adding $\mathrm{Zn}^{2+}$ on the adsorbent, Mg-Zn-Al HT was chosen with a $3: 1: 1$ molar ratio. Even with a small $\mathrm{Zn}^{2+}$ molar ratio, it has been able to increase the adsorption ability almost equal the addition of a larger number of moles. The increase of $\mathrm{Zn}^{2+}$ addition causes the surface of Mg-Zn-Al HT become more positively charged and 


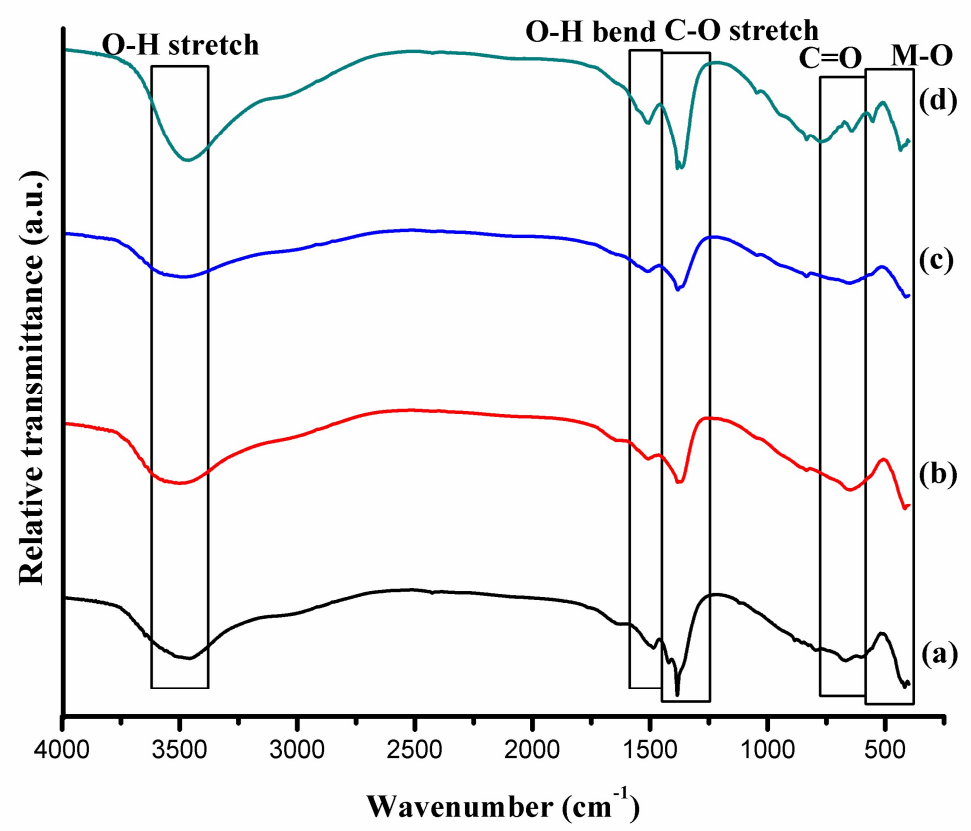

Figure 2. FTIR spectra of (a) Mg-Al-HT, (b) Mg-Al-Zn1-HT, (c) Mg-Al-Zn2-HT, (d) Mg-Al-Zn3-HT.

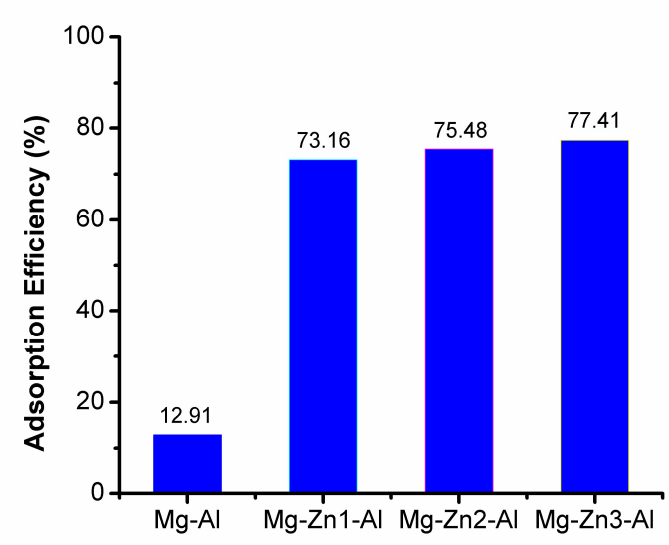

Figure 3. The effect of $\mathrm{Zn}^{2+}$ addition on the structure of $\mathrm{Mg}-\mathrm{Al} \mathrm{HT}$ on $\mathrm{Pb}^{2+}$ metal ions adsorption.

it will attract more hydroxide ions. Along with this, the hydroxide ion will attract $\mathrm{Pb}^{2+}$ which will form $\mathrm{Pb}(\mathrm{OH})_{2}$.

\subsubsection{Characterization of metal oxide FORMATION FROM Mg-Zn-Al HT}

The adsorbent of $\mathrm{Mg}-\mathrm{Zn}-\mathrm{Al} \mathrm{HT}$ and its oxides were characterized by the XRD to determine the effect of calcination on the formation of $\mathrm{Mg}-\mathrm{Zn}-\mathrm{Al} \mathrm{HT}$ oxide. The XRD diffractogram of Mg-Zn-Al HT and its oxides is shown in Fig. 4

It can be seen, in Fig. 4 that the calcination causes the intensity of the HT peak to decrease and also forms a new peak, namely MgO (JCPDS No.78-0430) and $\mathrm{ZnO}$ (JCPDS No.89-1397). The calcination treat- ment at $450^{\circ} \mathrm{C}$ causes a loss of water molecules and carbonate ions in the interlayer due to the damage of $\mathrm{Mg}-\mathrm{Zn}-\mathrm{Al} \mathrm{HT}$ structure. The FTIR spectrum of $\mathrm{Mg}-\mathrm{Zn}-\mathrm{Al} \mathrm{HT}$ and Mg-Zn-Al HT oxides are shown in Fig. 5 .

Based on Fig. 5, it can be seen that there is an absorption at the wavenumber $3525-3490 \mathrm{~cm}^{-1}$ which is identified as the absorption of $\mathrm{O}-\mathrm{H}$ group stretch. The stretched $\mathrm{O}-\mathrm{H}$ group is probably coming from hydroxyl groups, which bind to divalent and trivalent cation metals in the layer or can also be possible from $\mathrm{H}_{2} \mathrm{O}$ present in the interlayer [2, 5]. The absorption in the wavenumber $1607-1527 \mathrm{~cm}^{-1}$ is the absorption of the $\mathrm{O}-\mathrm{H}$ group bending of water molecules in the interlayer. A typical absorption of the $\mathrm{C}-\mathrm{O}$ group (carbonyl) of $\mathrm{CO}_{3}^{2-}$, which is the interlayer balancing anion, is shown by the absorption at wavenumbers $1384-1381 \mathrm{~cm}^{-1}$. The absorption of $\mathrm{C}=\mathrm{O}$ from carbonate vibrations is shown by the absorption at wavenumbers $648-636 \mathrm{~cm}^{-1}$. Absorption at wavenumbers $460-420 \mathrm{~cm}^{-1}$ is the absorption of $\mathrm{Mg}-\mathrm{OH}, \mathrm{Al}-$ $\mathrm{OH}, \mathrm{Zn}-\mathrm{OH}$ at the hydrotalcite layer in the octahedral coordination $[5]$.

\subsection{Effectiveness test of Mg-Zn-Al HT AND ITS OXIDE TO $\mathrm{Pb}^{2+}$ ADSORPTION}

The test results of the adsorption effectiveness of $\mathrm{Mg}$ $\mathrm{Zn}-\mathrm{Al} \mathrm{HT}$ and its oxidized form for $\mathrm{Pb}^{2+}$ removal are shown in Fig. 6.

As seen in Fig. 6, it appears that the adsorption ability of $\mathrm{Mg}-\mathrm{Zn}-\mathrm{Al} \mathrm{HT}$ oxide on $\mathrm{Pb}^{2+}$ metal is higher than that of Mg-Zn-Al HT. The high adsorption ability of $\mathrm{Mg}-\mathrm{Zn}-\mathrm{Al} \mathrm{HT}$ oxide due to the calcination treatment could disperse the metal cations in the layer 


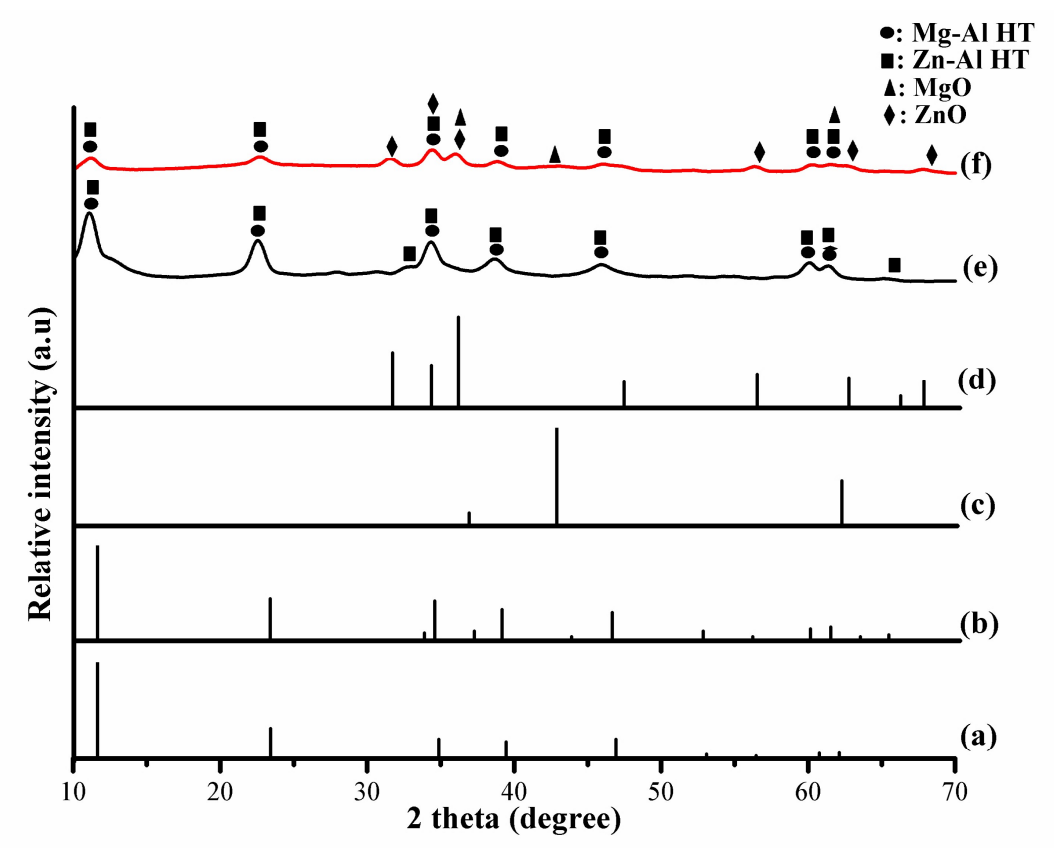

Figure 4. The diffractogram of (a) JCPDS Mg-Al HT (b) JCPDS Zn-Al HT (c) JCPDS MgO (d) JCPDS ZnO (e) Mg-Zn-Al HT and (f) Mg-Zn-Al HT oxide.

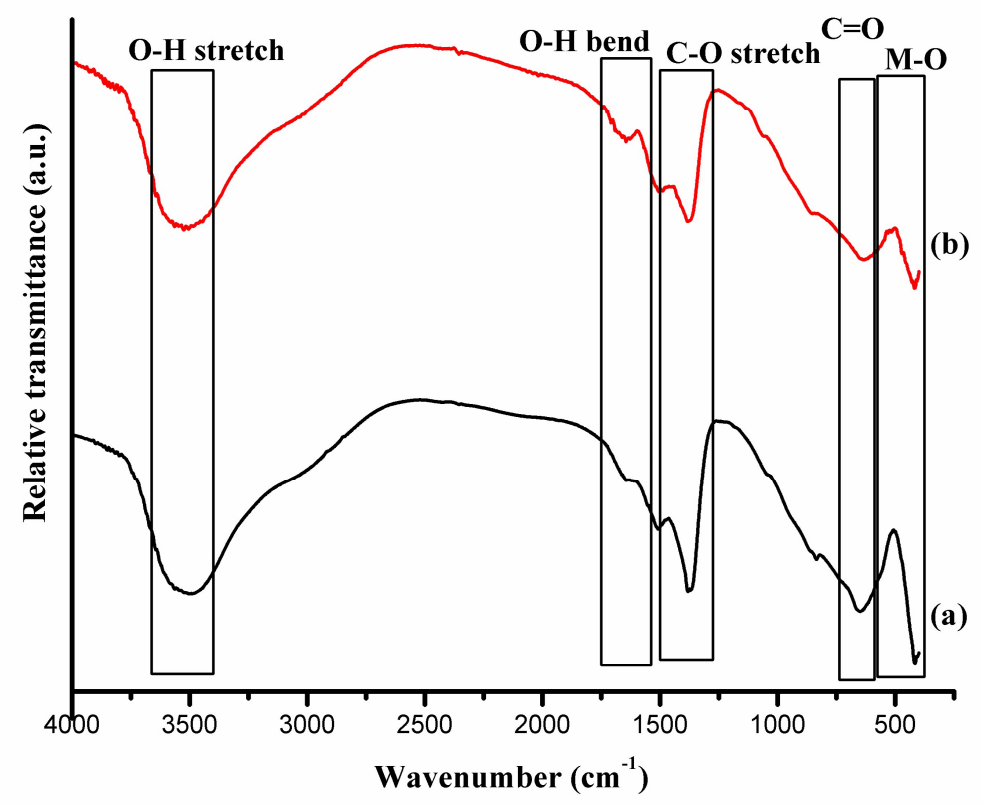

Figure 5. The FTIR spectrum of (a) Mg-Zn-Al HT and (b) Mg-Zn-Al HT oxide. 


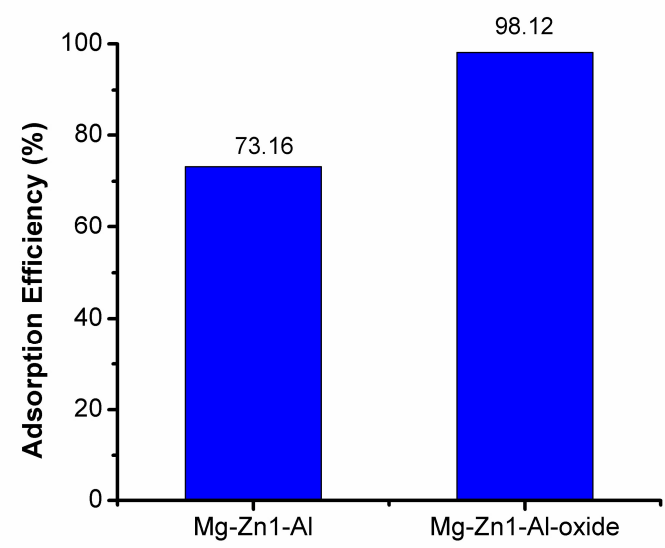

Figure 6. Adsorption efficiency of Mg-Zn1-Al HT and $\mathrm{Mg}-\mathrm{Zn} 1-\mathrm{Al} \mathrm{HT}$ oxide to $\mathrm{Pb}^{2+}$ metal ion.

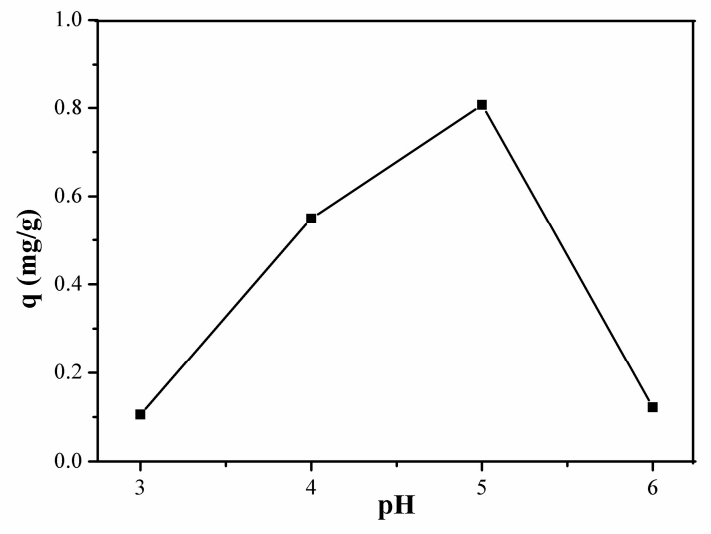

FiguRE 7. Effect of $\mathrm{pH}$ on $\mathrm{Pb}^{2+}$ metal adsorption efficiency.

homogeneously. As a result, the $\mathrm{O}-\mathrm{H}$ group on the layer is evenly distributed on the entire surface of the $\mathrm{Mg}-\mathrm{Zn}-\mathrm{Al}$ oxide, which can then precipitate $\mathrm{Pb}^{2+}$ more effectively on the surface of the layer as $\mathrm{Pb}(\mathrm{OH})_{2}$. In addition, the structure regeneration of $\mathrm{Mg}-\mathrm{Zn}$-Al HT when dispersed into the water-known as the 'memory effect' tends to attract hydroxide ions on the surface of the positively charged $\mathrm{Mg}-\mathrm{Zn}-\mathrm{Al} \mathrm{HT}$ layer so that it can precipitate metal on the surface of Mg-Zn-Al HT [2, 11].

\subsection{Adsorption studies of $\mathrm{Pb}^{2+}$ Using Mg-Zn-Al HT OXIDE}

\subsubsection{Optimum PH Determination of $\mathrm{Pb}\left(\mathrm{NO}_{3}\right)_{2}$ SOLUTION}

The $\mathrm{pH}$ variations were $3,4,5$, and 6 . The effect of the $\mathrm{pH}$ variation on the $\mathrm{Pb}^{2+}$ ions adsorption efficiency is shown in Fig 7

According to Fig. 7] it can be seen that the optimum $\mathrm{pH}$ condition is achieved at $\mathrm{pH} 5$. Similar results have been reported in previous studies by Yang et al., 2016 [3] that determined the optimum $\mathrm{pH}$ of $\mathrm{Pb}\left(\mathrm{NO}_{3}\right)_{2}$ to

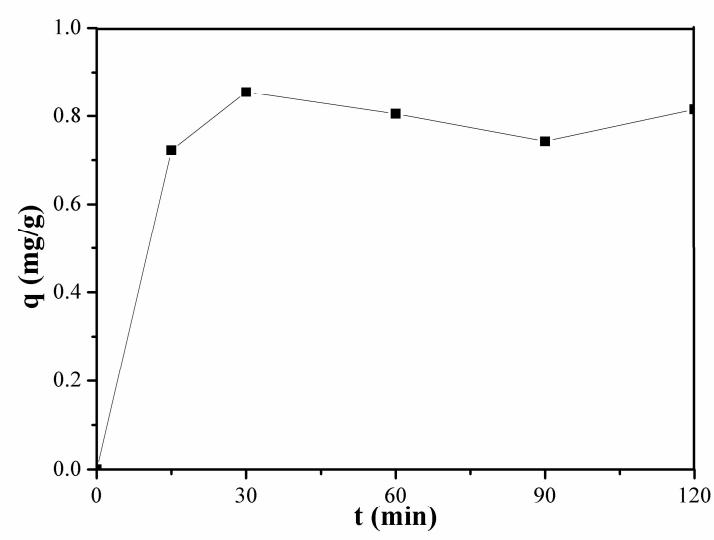

Figure 8. Effect of contact time on $\mathrm{Pb}^{2+}$ metal adsorption efficiency.

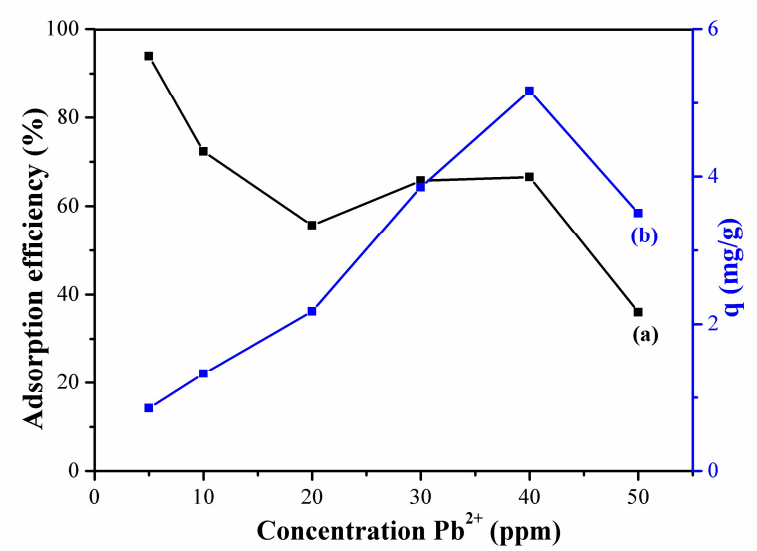

FiguRE 9. Effect of initial concentration on $\mathrm{Pb}^{2+}$ metal adsorption on (a) adsorption efficiency and (b) adsorption capacity.

be at $\mathrm{pH} 5$. The adsorption efficiency of $\mathrm{Pb}^{2+}$ ion at $\mathrm{pH} 5$ is $92.23 \%$ with an adsorption capacity of $0.81 \mathrm{mg} / \mathrm{g}$. At pH 3, the adsorption efficiency only reached $10.83 \%$ and at $\mathrm{pH}$ above 5 , the adsorption efficiency decreases.

\subsubsection{EFFECT OF CONTACT TIME}

The profile of the contact time variation effect to the $\mathrm{Pb}^{2+}$ adsorption efficiency is illustrated as shown in Fig. 8

Under certain conditions, based on Fig. 8, the adsorption percentage decreases and then becomes constant. The optimum contact time is 30 minutes with an adsorption efficiency of $93.88 \%$ and an adsorption capacity of $0.86 \mathrm{mg} / \mathrm{g}$.

\subsubsection{EFFECT OF INITIAL CONCENTRATION}

The effect of the initial concentration on the $\mathrm{Pb}^{2+}$ adsorption was carried out at concentrations of 5,10 , $20,30,40$, and $50 \mathrm{ppm}$. The profile of the effect of the 
initial concentration on the efficiency and adsorption capacity is presented in Fig. 9

It is known that the initial concentration of $\mathrm{Pb}\left(\mathrm{NO}_{3}\right)_{2}$ solution is inversely proportional to the adsorption ability. Fig. 9(a) shows that the decrease in adsorption efficiency occurs as the initial concentration of $\mathrm{Pb}^{2+}$ increases. According to Elsayed et al., 2016 [2], the decreasing of the adsorption efficiency occurs at higher concentrations; the amount of $\mathrm{Pb}^{2+}$ ions in solution is not proportional to the number of available adsorbent particles. Hence, the surface of the adsorbent will reach a saturation point and then the adsorption efficiency will decrease. While Figure 9(b) shows that the increasing of the adsorbed$\mathrm{Pb}^{2+}$ per gram adsorbent is proportional to the initial concentration of $\mathrm{Pb}^{2+}$ solution. When the adsorbate concentration increases, more molecules are adsorbed per unit surface area of the adsorbent. The increasing concentration of $\mathrm{Pb}^{2+}$ will give the thrust of $\mathrm{Pb}^{2+}$ ions to be adsorbed in the adsorbent pores [37].

\subsubsection{Characterization of $\mathrm{Mg}-\mathrm{Zn}-\mathrm{Al} \mathrm{HT}$ OXIDE ADSORBENT AFTER $\mathrm{Pb}^{2+}$ ADSORPTION}

The characterization of the Mg-Zn-Al HT oxide adsorbent after the $\mathrm{Pb}^{2+}$ adsorption process was conducted with the FTIR and XRD. The functional group of $\mathrm{Mg}-\mathrm{Zn}-\mathrm{Al} \mathrm{HT}$ oxide adsorbent before and after the $\mathrm{Pb}^{2+}$ adsorption are shown in Fig. 10 .

Figure 10 shows an absorption of $\mathrm{O}-\mathrm{H}$ group stretching at a wavenumber of $3525 \mathrm{~cm}^{-1}$, in the $\mathrm{Mg}$ Zn-Al HT before the adsorption. The similar peak appears at $3480 \mathrm{~cm}^{-1}$ in the $\mathrm{Mg}-\mathrm{Zn}-\mathrm{Al} \mathrm{HT}$ after the adsorption. Meanwhile, the absorption of $\mathrm{O}-\mathrm{H}$ groups bending from $\mathrm{H}_{2} \mathrm{O}$ molecules in the interlayer before adsorption at wavenumbers of $1527 \mathrm{~cm}^{-1}$ and after the adsorption at $1575 \mathrm{~cm}^{-1}$. The typical absorption of the $\mathrm{C}-\mathrm{O}$ group (carbonyl) of $\mathrm{CO}_{3}{ }^{2-}$ that is the interlayer balancing anion before the adsorption is shown at $1381 \mathrm{~cm}^{-1}$ and after the adsorption, it is shown at $1379 \mathrm{~cm}^{-1}$. The absorption of $\mathrm{C}=\mathrm{O}$ from carbonate vibrations is shown by absorption at 636 $610 \mathrm{~cm}^{-1}$. Absorption at $460-420 \mathrm{~cm}^{-1}$ is the absorption of $\mathrm{Mg}-\mathrm{OH}, \mathrm{Al}-\mathrm{OH}, \mathrm{Zn}-\mathrm{OH}$ on the hydrotalcite layer in octahedral coordination [5].

The diffractogram of Mg-Zn-Al HT oxide before and after the adsorption is shown in Fig. 11.

Based on Fig. 11, it can be seen that the peak of metal oxides, such as $\mathrm{MgO}$ and $\mathrm{ZnO}$, formed by the calcination treatment is not formed again after the adsorption process. The intensity of typical HT peaks also increases after the adsorption process due to the nature of the memory effect on the HT. The structure reverts back to the initial $\mathrm{Mg}-\mathrm{Zn}-\mathrm{Al} \mathrm{HT}$ structure after being dispersed in a solution.

The elemental composition of Mg-Zn-Al HT oxide adsorbent before and after the adsorption of $\mathrm{Pb}^{2+}$ ions was analysed by Scanning Electron MicroscopyEnergy Dispersive X-Ray (SEM-EDX). Each element's percentage in the $\mathrm{Mg}-\mathrm{Zn}-\mathrm{Al}$ HT oxide is presented in Table 1.

According to the data in Table 1, it can be seen that $\mathrm{Pb}$ is present in the $\mathrm{Mg}-\mathrm{Zn}-\mathrm{Al} \mathrm{HT}$ oxide after the adsorption. It proves that the $\mathrm{Pb}^{2+}$ ions were adsorbed onto it. The morphology of Mg-Zn-Al HT oxide adsorbent before and after the $\mathrm{Pb}^{2+}$ adsorption process was characterized by the SEM, and the result is depicted in Fig. 12

Figure 12(a) shows that on the surface of the MgZn-Al HT oxide adsorbent, there are hollow holes with different shapes and sizes, while Fig. 12(b) indicates the adsorbent surface tends to be coarser with more closed holes. The closed-holes indicate that the holes were filled with the $\mathrm{Pb}^{2+}$ adsorbed on the surface of Mg-Zn-Al HT oxide during the adsorption. Similar result had been reported by Mostafa et al., 2016 [12] in his study using Co-Mo hydrotalcite adsorbents.

\subsection{DETERMINATION OF ADSORPTION KINETICS}

The kinetic models used in this study are a pseudo first order (3) and pseudo second order (4) kinetics models [3].

$$
\log \left(q_{e}-q_{t}\right)=\log q_{e}-\frac{k_{1}}{2.303} t
$$

where $q_{e}$ is the quantity of the solute adsorbed at an equilibrium per weight unit of adsorbent $(\mathrm{mg} / \mathrm{g}), q_{t}$ is the quantity of the solute adsorbed at any time $(\mathrm{mg} / \mathrm{g})$, and $k_{1}$ is the sorption constant. For the pseudo-secondorder model, the kinetic data were examined using a formula shown below:

$$
\frac{1}{q_{t}}=\frac{1}{k_{2} q_{e}^{2}}+\frac{1}{q_{t}}
$$

where $k_{2}(\mathrm{~g} /(\mathrm{mg} \cdot \mathrm{min}))$ is the pseudo-second-order rate constant; $t$ ( $\mathrm{min})$ is the sorption time; $q_{e}(\mathrm{mg} / \mathrm{g})$ is the equilibrium $\mathrm{Pb}^{2+}$ adsorption capacity of the adsorbent, and $q_{t}(\mathrm{mg} / \mathrm{g})$ is the sorption capacity at a time $t$.

Figure 13 shows the kinetic curve of the Mg-Zn1-Al HT oxide adsorption on $\mathrm{Pb}^{2+}$ metal. A comparison of adsorption kinetics parameters is presented in Table 2 .

Based on the adsorption kinetics parameter data presented in Table 2, it can be seen that the adsorption of $\mathrm{Pb}^{2+}$ using $\mathrm{Mg}-\mathrm{Zn}-\mathrm{Al} \mathrm{HT}$ oxide tends to follow the pseudo second order equation. It is proved by the $R^{2}$ value for the pseudo second order, which is closer to one. The pseudo second order adsorption kinetics indicate that the adsorption occurs chemically. A research conducted on $\mathrm{Pb}^{2+}$ adsorption using the HT tends to follow a pseudo second order as in the study of Mostafa et al., 2016 12 using Co-Mo HT and Yang et al., 2016 [3] using modified Mg-Al HT palygorskite.

\subsection{Determination OF ADSORPTION ISOTHERM}

The type of the adsorption is obtained by plotting the adsorption data based on the Langmuir and Fre- 


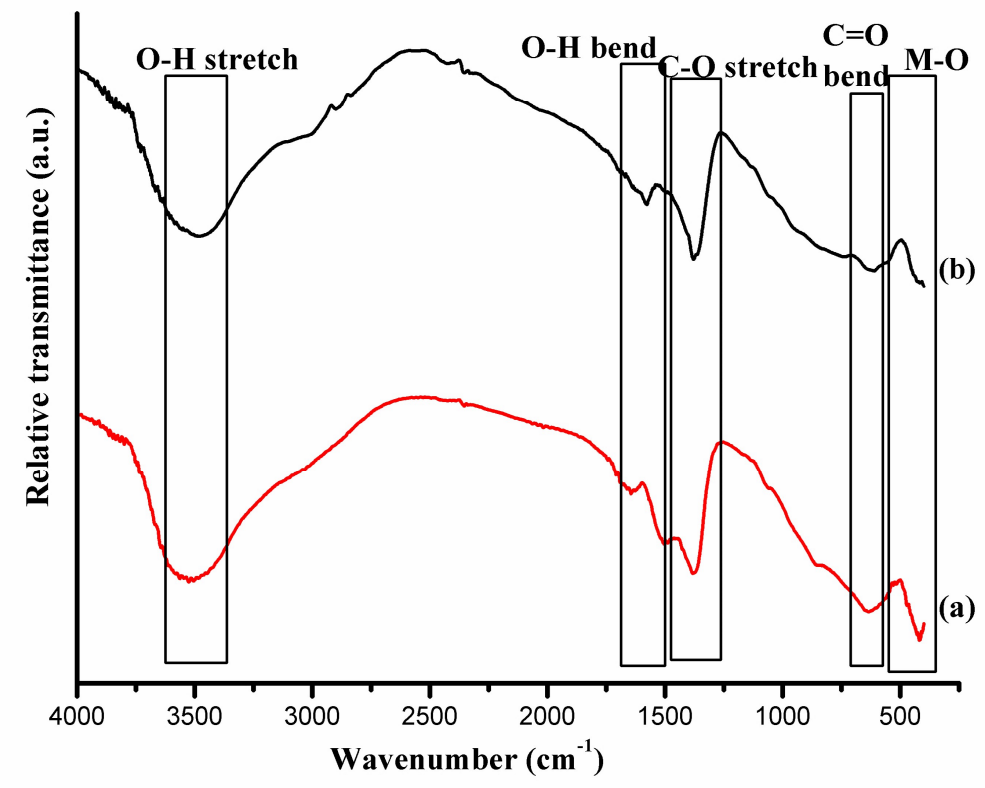

Figure 10. The functional group of Mg-Zn-Al HT oxide adsorbent (a) before and (b) after adsorption.

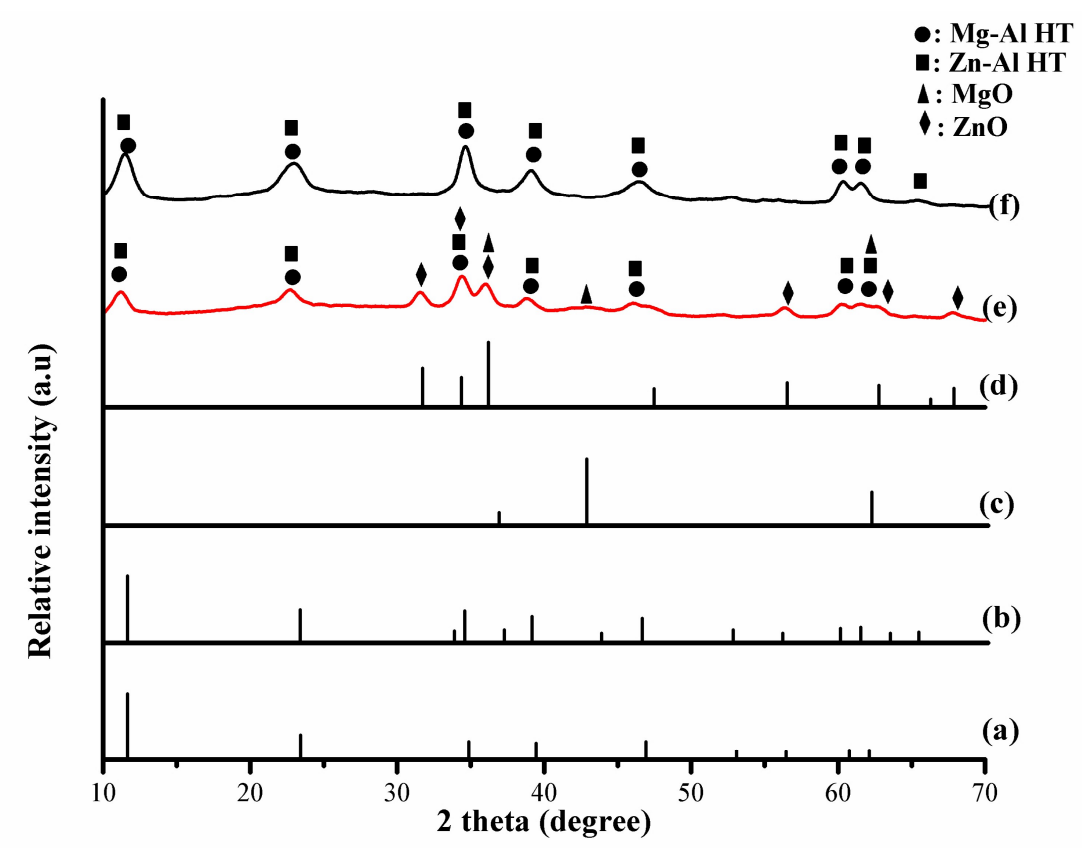

Figure 11. Diffractogram of (a) JCPDS Mg-Al HT (b) JCPDS Zn-Al HT (c) JCPDS MgO (d) JCPDS ZnO (e) $\mathrm{Mg}-\mathrm{Zn}-\mathrm{Al}$ HT oxide before adsorption and (f) Mg-Zn-Al HT oxide after adsorption.

\begin{tabular}{lcccccc}
\hline \multirow{2}{*}{$\begin{array}{l}\text { Adsorption } \\
\text { process }\end{array}$} & \multicolumn{6}{c}{ Element (\%) } \\
\cline { 2 - 7 } & $\mathrm{C}$ & $\mathrm{O}$ & $\mathrm{Mg}$ & $\mathrm{Al}$ & $\mathrm{Zn}$ & $\mathrm{Pb}$ \\
\hline Before & - & 34.50 & 27.36 & 11.10 & 27.04 & - \\
After & 37.11 & 24.74 & 16.27 & 10.00 & 20.60 & 1.27 \\
\hline
\end{tabular}

TABLE 1. The EDX result of Mg-Zn-Al HT before and after adsorption. 


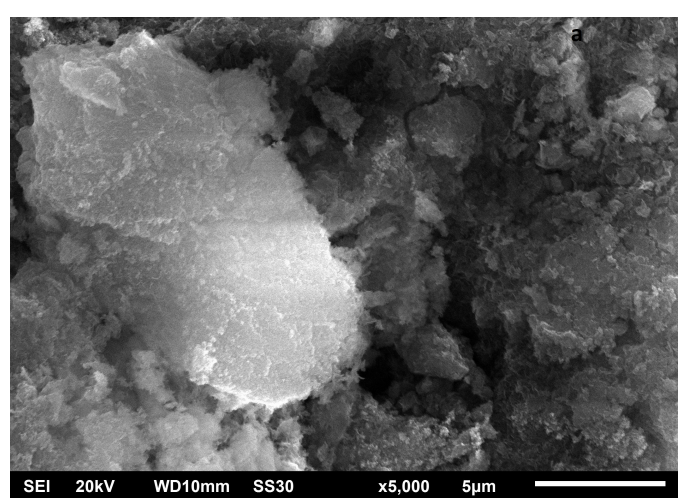

(A).

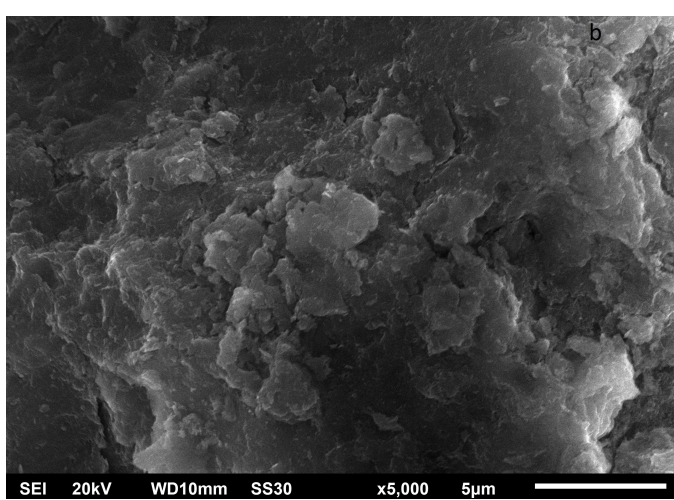

(B).

Figure 12. Morphology of Mg-Zn-Al HT (a) before and (b) after adsorption.

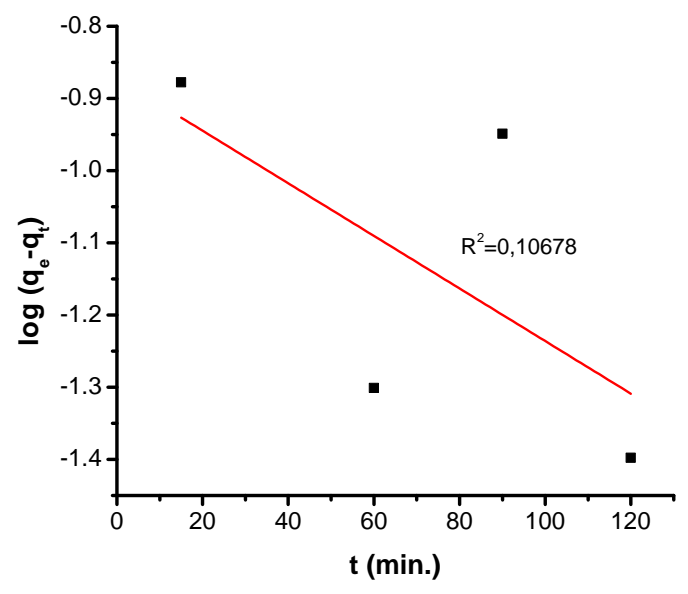

(A).

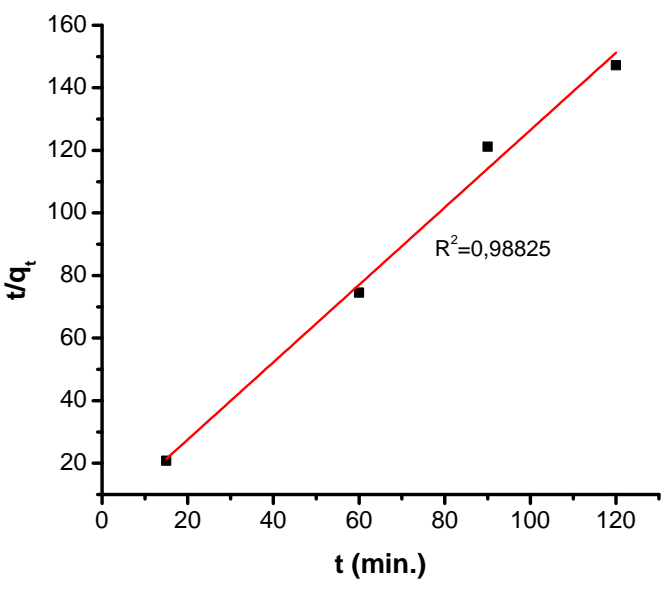

(B).

Figure 13. Adsorption kinetics curve of (a) pseudo first order and (b) pseudo second order.

\begin{tabular}{cccccc}
\hline \multicolumn{2}{c}{ Pseudo-first-order } & \multicolumn{3}{c}{ Pseudo-double-order } \\
$k_{1}(1 / \mathrm{min})$ & $q_{e}(\mathrm{mg} / \mathrm{g})$ & $R^{2}$ & $k_{2}(\mathrm{~g} / \mathrm{mg} \cdot \mathrm{min})$ & $q_{e}(\mathrm{mg} / \mathrm{g})$ & $R^{2}$ \\
\hline 0.0084 & 0.134 & 0.405 & 0.544 & 0.809 & 0.988 \\
\hline
\end{tabular}

TABlE 2. Pseudo-first and pseudo-second-order models for the sorption of $\mathrm{Pb}^{2+}$ ions onto $\mathrm{Mg}-\mathrm{Zn}-\mathrm{Al} \mathrm{HT}$ oxide.

\begin{tabular}{ccccccc}
\hline \multicolumn{2}{c|}{ Freundlich } & \multicolumn{5}{c}{ Langmuir } \\
$K_{F}(\mathrm{mg} / \mathrm{g})$ & $n$ & $R^{2}$ & $K_{L}(\mathrm{~L} / \mathrm{mmol})$ & $E_{a}(\mathrm{~kJ} / \mathrm{mol})$ & $R^{2}$ & $Q_{m}(\mathrm{mg} / \mathrm{g})$ \\
\hline 0.044 & 2.711 & 0.735 & 90.644 & 28.756 & 0.876 & 3.916 \\
\hline
\end{tabular}

TABLE 3. Adsorption isotherm parameters for sorption of $\mathrm{Pb}^{2+}$ ions onto $\mathrm{Mg}-\mathrm{Zn}-\mathrm{Al} \mathrm{HT}$ oxide.

\begin{tabular}{lcc}
\hline Adsorbent & $\begin{array}{c}\text { Adsorption capacity } \\
\text { of } \mathrm{Pb}^{2+}(\mathrm{mg} / \mathrm{g})\end{array}$ & References \\
\hline Cedar leaf ash & 8.000 & Hafshejani et al. [38] \\
Expanded perlite (EP) & 13.390 & Sari et al. [18] \\
Almond shells & 4.500 & Brudey et al. [39] \\
ZnO nanoparticles & 6.700 & Ma et al. [40] \\
Mg-Zn-Al HT & 3.916 & Present study \\
\hline
\end{tabular}

TABLE 4. The comparison of $\mathrm{Pb}^{2+}$ adsorption capacity on some adsorbent. 


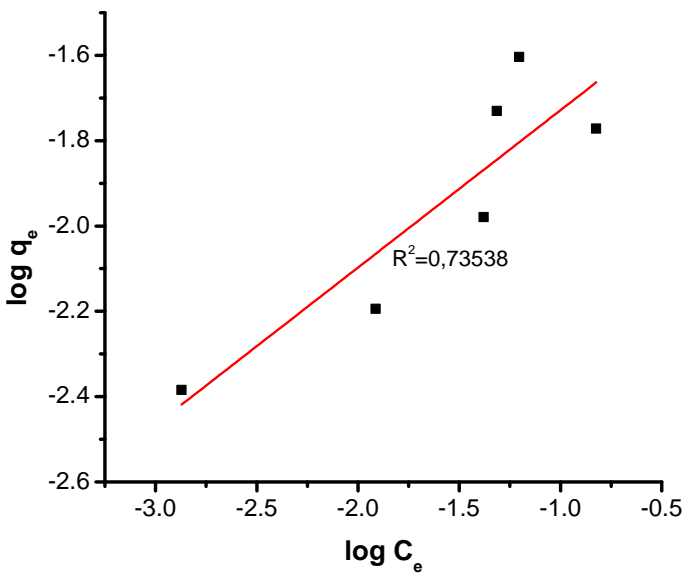

(A).

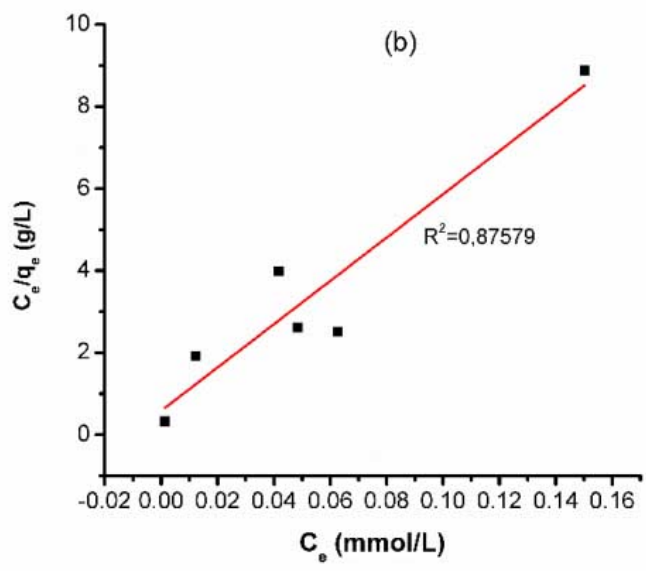

(B).

FIGURE 14. Adsorption isotherm curve of (a) Freundlich and (b) Langmuir.

undlich isotherm adsorption. The results are shown in Fig. 14. Meanwhile, the isotherm parameters are listed in Table 3 .

Table 3 shows that the $\mathrm{Pb}^{2+}$ adsorption tends to follows the Langmuir isotherm with an adsorption capacity of $3.916 \mathrm{mg} / \mathrm{g}$, the $R^{2}$ value is close to one. It indicates that the $\mathrm{Pb}^{2+}$ adsorption occurs due to a chemical bonding between the $\mathrm{Pb}^{2+}$ and hydroxide groups located on the surface of the $\mathrm{Mg}-\mathrm{Zn}-\mathrm{Al} \mathrm{HT}$ oxide layer. The Langmuir isotherm model implies a homogeneous distribution of a single layer adsorbedmolecules on the surface of the adsorbent. It is possibly caused by each hydroxide group as the active side on the surface of $\mathrm{Mg}-\mathrm{Zn}-\mathrm{Al} \mathrm{HT}$ only adsorbing one $\mathrm{Pb}^{2+}$ ion.

Table 4 portrays other adsorbents used for a $\mathrm{Pb}^{2+}$ removal from aqueous solutions. These results indicate that the studied adsorbent is not appropriate for a $\mathrm{Pb}^{2+}$ removal from an aqueous solution without any modifications.

\section{Conclusion}

The molar ratio variation of $\mathrm{Mg}-\mathrm{Zn}-\mathrm{Al} \mathrm{HT}$ increases the positive charge of $\mathrm{Mg}-\mathrm{Zn}-\mathrm{Al} \mathrm{HT}$. The calcination also increase the adsorption effectivity of $\mathrm{Pb}^{2+}$. The adsorption, whether to Mg-Zn-Al HT or Mg-Zn-Al HT oxide, follows a pseudo-second-order kinetics model. While the isotherm follows the Langmuir model with a maximum adsorption capacity of $3.916 \mathrm{mg} / \mathrm{g}$ at $\mathrm{pH} 5$ and the optimum contact time is $30 \mathrm{~min}$ at a room temperature.

\section{ACKNOWLEDGEMENTS}

The authors thank to Sebelas Maret University (Universitas Sebelas Maret) for providing financial support on this work under the scheme of 'Hibah Mandatory PNBP UNS, 2019 Grant'.

\section{REFERENCES}

[1] F. Cavani, F. Trifirò, A. Vaccari. Hydrotalcite-type anionic clays: Preparation, properties and applications. Catalysis Today 11(2):173-301, 1991. DOI:10.1016/0920-5861(91)80068-K

[2] M. El-Sayed, G. Eshaq, A. E. ElMetwally. Adsorption of heavy metals from aqueous solutions by $\mathrm{Mg}-\mathrm{Al}-\mathrm{Zn}$ mingled oxides adsorbent. Water Science and Technology 74:1644-1657, 2016. DOI:10.2166/wst.2016.329

[3] F. Yang, S. Sun, X. Chen, et al. Mg-Al layered double hydroxides modified clay adsorbents for efficient removal of $\mathrm{Pb} 2+, \mathrm{Cu} 2+$ and $\mathrm{Ni} 2+$ from water. Applied Clay Science 123:134-140, 2016. DOI:10.1016/j.clay.2016.01.026.

[4] M. Ghashghaee, S. Shirvani, V. Farzaneh, S. Sadjadi. Hydrotalcite-impregnated copper and chromium-doped copper as novel and efficient catalysts for vapor-phase hydrogenation of furfural: Effect of clay pretreatment. Brazilian Journal of Chemical Engineering 35:669-678, 2018. DOI:10.1590/0104-6632.20180352s20160703.

[5] L. Cocheci, P. Barvinschi, R. Pode, et al. Structural characterization of some $\mathrm{Mg} / \mathrm{Zn}-\mathrm{Al}$ type hydrotalcites prepared for chromate sorption from wastewater. Chemical Bulletin of POLITEHNICA University of Timisoara 55:40-45, 2010.

[6] T. Kameda, T. Yoshioka, K. Watanabe, et al. Dehydrochlorination behavior of a chloride ion-intercalated hydrotalcite-like compound during thermal decomposition. Applied Clay Science 35:173-179, 2007. DOI:10.1016/j.clay.2006.08.010

[7] M. Bouraada, F. Belhalfaoui, M. S. Ouali, L. De Ménorval. Sorption study of an acid dye from an aqueous solution on modified $\mathrm{Mg}-\mathrm{Al}$ layered double hydroxides. Journal of Hazardous Materials 163:463-467, 2009. DOI:10.1016/j.jhazmat.2008.06.108

[8] K. Abderrazek, F. Srasra Najoua, E. Srasra. Synthesis and characterization of [Zn-Al] LDH: Study of the effect of calcination on the photocatalytic activity. Applied Clay Science 119:229-235, 2016. DOI:10.1016/j.clay.2015.10.014. 
[9] M. Jenisha Barnabas, S. Parambadath, A. Mathew, et al. Highly efficient and selective adsorption of In3+ on pristine $\mathrm{Zn} / \mathrm{Al}$ layered double hydroxide (Zn/Al-LDH) from aqueous solutions. Journal of Solid State Chemistry 233:133-142, 2016. DOI:10.1016/j.jssc.2015.10.001.

[10] W. Wang, J. Zhou, G. Achari, et al. Cr(VI) removal from aqueous solutions by hydrothermal synthetic layered double hydroxides: Adsorption performance, coexisting anions and regeneration studies. Colloids and Surfaces A: Physicochemical and Engineering Aspects 457:33-40, 2014. DOI:10.1016/j.colsurfa.2014.05.034.

[11] A. A. Bakr, G. Eshaq, A. M. Rabie, et al. Copper ions removal from aqueous solutions by novel $\mathrm{Ca}-\mathrm{Al}-\mathrm{Zn}$ layered double hydroxides. Desalination and Water Treatment 57(27):12632-12643, 2016. DOI:10.1080/19443994.2015.1051126.

[12] M. Mostafa, A.-S. A. Bakr, A. El Naggar, E.-S. A. Sultan. Water decontamination via the removal of $\mathrm{Pb}$ (II) using a new generation of highly energetic surface nano-material: $\mathrm{Co}(+2) \mathrm{Mo}(+6) \mathrm{LDH}$. Journal of colloid and interface science 461:261-272, 2015. DOI:10.1016/j.jcis.2015.08.060

[13] B. Hassiba, M. Bouraada, L. Charles Deménorval. Removal of indigo carmine and green bezanyl-F2B from water using calcined and uncalcined $\mathrm{Zn} / \mathrm{Al}+$ Fe layered double hydroxide. Journal of Water Reuse and Desalination 7:152-161, 2017. DOI:10.2166/wrd.2016.042

[14] A. M. Abu-Dief, M. M. Zikry. Adsorption of the heavy metal ions onto bio sorbents: A review. International Journal of Nanomaterials and Chemistry 4:27-39, 2018. DOI:10.18576/ijnc/040301.

[15] A. Sarı, M. Tuzen. Kinetic and equilibrium studies of $\mathrm{Pb}(\mathrm{II})$ and $\mathrm{Cd}(\mathrm{II})$ removal from aqueous solution onto colemanite ore waste. Desalination 249:260-266, 2009. DOI:10.1016/j.desal.2008.12.057

[16] M. Ghashghaee, V. Farzaneh. Removal of Cr(VI) species from aqueous solution by different nanoporous materials. Iranian Journal of Toxicology 10:15-21, 2016. DOI:10.29252/arakmu.10.6.15.

[17] F. Fu, Q. Wang. Removal of heavy metal ions from wastewaters: A review. Journal of environmental management 92:407-418, 2011. DOI:10.1016/j.jenvman.2010.11.011

[18] A. Sari, M. Tuzen, D. Çitak, M. Soylak. Adsorption characteristics of $\mathrm{Cu}(\mathrm{II})$ and $\mathrm{Pb}(\mathrm{II})$ onto expanded perlite from aqueous solution. Journal of Hazardous Materials 148:387-394, 2007.

DOI:10.1016/j.jhazmat.2007.02.052

[19] K. Yang, L.-g. Yan, Y.-m. Yang, et al. Adsorptive removal of phosphate by $\mathrm{Mg}-\mathrm{Al}$ and $\mathrm{Zn}-\mathrm{Al}$ layered double hydroxides: Kinetics, isotherms and mechanisms. Separation and Purification Technology 124:36-42, 2014. DOI:10.1016/j.seppur.2013.12.042

[20] E. Heraldy, W. W. Lestari, D. Permatasari, D. D. Arimurti. Biosorbent from tomato waste and apple juice residue for lead removal. Journal of Environmental Chemical Engineering 6:1201-1208, 2018. DOI:h10.1016/j.jece.2017.12.026
[21] K. Jiang, T.-H. Sun, N. Sun, H.-B. Li. Adsorption characteristics of copper, lead, zinc and cadmium ions by tourmaline. Journal of environmental sciences (China) 18:1221-1225, 2006. DOI:10.1016/S1001-0742(06)60066-1

[22] A. Azzam, S. El-Wakeel, B. B. Mostafa, M. F. El-Shahat. Removal of $\mathrm{Pb}, \mathrm{Cd}, \mathrm{Cu}$ and $\mathrm{Ni}$ from aqueous solution using nano scale zero valent iron particles. Journal of Environmental Chemical Engineering 4:2196-2206, 2016. DOI:10.1016/j.jece.2016.03.048.

[23] L. Monser, N. Adhoum. Tartrazine modified activated carbon for the removal of $\mathrm{Pb}(\mathrm{II}), \mathrm{Cd}(\mathrm{II})$ and Cr(III). Journal of Hazardous Materials 161:263-269, 2009. DOI:10.1016/j.jhazmat.2008.03.120

[24] U. Wingenfelder, C. Hansen, G. Furrer, R. Schulin. Removal of heavy metals from mine waters by natural zeolites. Environmental Science $\mathcal{E}$ Technology 39:4606-4613, 2005. DOI:10.1021/es048482s

[25] J. Perić, M. Trgo, N. V. Medvidović. Removal of zinc, copper and lead by natural zeolite - a comparison of adsorption isotherms. Water Research 38:1893-1899, 2004. DOI:10.1016/j.watres.2003.12.035

[26] M. Ghashghaee, M. Ghambarian. Adsorption of toxic mercury, lead, cadmium, and arsenic ions on black phosphorous nanosheet: first-principles calculations. Structural Chemistry 30:85-96, 2018. DOI:10.1007/s11224-018-1173-6.

[27] M. Madhava Rao, D. Ramana, K. Seshaiah, et al. Removal of some metal ions by activated carbon prepared from Phaseolus aureus hulls. Journal of Hazardous Materials 166:1006-1013, 2009. DOI:10.1016/j.jhazmat.2008.12.002

[28] X. Li, J. Xing, C. Zhang, et al. Adsorption of lead on sulfur-doped graphitic carbon nitride nanosheets: Experimental and theoretical calculation study. ACS Sustainable Chemistry \& Engineering 6:10606-10615, 2018. DOI:10.1021/acssuschemeng.8b01934.

[29] S. Basahel, S. Al-Thabaiti, N. Katabathini, et al. Nanostructured Mg-Al hydrotalcite as catalyst for fine chemical synthesis. Journal of Nanoscience and Nanotechnology 14:1931-1946, 2014. DOI:10.1166/jnn.2014.9193

[30] L. Abdel-Rahman, A. Abu-Dief, M. A. Abd-El Sayed, M. M. Zikry. Nano sized moringa oleifera an effective strategy for $\mathrm{Pb}(\mathrm{II})$ ions removal from aqueous solution. Chemistry and Materials Research 8:8-22, 2016.

[31] L. Abdel-Rahman, A. Abudief, B. S. F. Al-Farhan, M. M. Zikry. Removal of toxic $\mathrm{Pb}(\mathrm{II})$ ions from aqueous solution by nano sized flamboyant pod (Delonix regia). Archives in Chemical Research 01:1-10, 2016. DOI:10.21767/2572-4657.100003

[32] L. Rodriguez-Chiang, J. Llorca, O. Dahl. Effect of $\mathrm{Fe}-\mathrm{Zn}-\mathrm{Mg}-\mathrm{Al}$ hydrotalcites on the methane potential of synthetic sulfate-containing wastewater. Journal of Water Process Engineering 10:120-127, 2016. DOI:10.1016/j.jwpe.2016.03.001

[33] M. Ghashghaee, V. Farzaneh. Nanostructured hydrotalcite-supported RuBaK catalyst for direct conversion of ethylene to propylene. Russian Journal of Applied Chemistry 91:972-976, 2018. DOI:10.1134/S1070427218060149. 
[34] J. Valente, J. Hernández-Cortez, M. Sánchez-Cantú, et al. Calcined layered double hydroxides $\mathrm{Mg}-\mathrm{Me}-\mathrm{Al}(\mathrm{Me}$ : $\mathrm{Cu}, \mathrm{Fe}, \mathrm{Ni}, \mathrm{Zn}$ ) as bifunctional catalysts. Catalysis Today 150:340-345, 2010. DOI:10.1016/j.cattod.2009.08.020

[35] K. Abou-El-Sherbini, I. M. Kenawy, M. A. Hafez, et al. Synthesis of novel CO32-/Cl-bearing $3(\mathrm{Mg}+\mathrm{Zn}) /(\mathrm{Al}+\mathrm{Fe})$ layered double hydroxides for the removal of anionic hazards. Journal of Environmental Chemical Engineering 3:2707-2721, 2015. DOI:10.1016/j.jece.2015.09.015.

[36] E. Heraldy, S. Santosa, Triyono, K. Wijaya. Anionic and cationic dyes removal from aqueous solutions by adsorption onto synthetic $\mathrm{Mg} / \mathrm{Al}$ hydrotalcite-like compound. Indonesian Journal of Chemistry 2015:234-241, 2015. DOI:10.22146/ijc.21190

[37] L. Wu, L. Melton, L. Sanguansri, M. A. Augustin. The batch adsorption of the epigallocatechin gallate onto apple pomace. Food Chemistry 160:260-265, 2014. DOI:10.1016/j.foodchem.2014.03.098
[38] L. Divband Hafshejani, S. Nasab, R. Mafi Gholami, et al. Removal of zinc and lead from aqueous solution by nanostructured cedar leaf ash as biosorbent. Journal of Molecular Liquids 211:448-456, 2015. DOI:10.1016/j.molliq.2015.07.044.

[39] T. Brudey, L. Largitte, C. Jean-Marius, et al. Adsorption of lead by chemically activated carbons from three lignocellulosic precursors. Journal of Analytical and Applied Pyrolysis 120:450-463, 2016. DOI:10.1016/j.jaap.2016.06.018

[40] M. Xingfa, Y. Wang, M. Gao, et al. A novel strategy to prepare $\mathrm{ZnO} / \mathrm{PbS}$ heterostructured functional nanocomposite utilizing the surface adsorption property of $\mathrm{ZnO}$ nanosheets. Catalysis Today 158:459-463, 2010. DOI:10.1016/j.cattod.2010.07.013 